\title{
SOUTH AFRICAN GRADE 11 PHYSICAL SCIENCES LEARNERS' PERCEPTIONS OF SCIENTIFIC INQUIRY
}

\author{
Rosemary Zunga, \& Sam Ramaila \\ Department of Science and Technology Education, University of Johannesburg (South Africa)
}

\begin{abstract}
This study explored South African Grade 11 Physical Sciences learners' perceptions of their experiences of scientific inquiry within the context of science classrooms. The study adopted a case study design and involved purposively selected Grade 11 physical sciences learners from two South African township schools. Data was collected by administering a validated Learner Perceptions of Classroom Inquiry (LPCI) instrument developed by Dudu and Vhurumuku (2012) with the participants. The study revealed that the learners held mixed conceptions about the nature of scientific inquiry. A substantial number of learners held naïve and incoherent views about the nature of scientific inquiry. The findings have profound implications for meaningful enactment of contemporary pedagogic approaches such as inquiry-based learning in various instructional settings. Theoretical implications for coherent development of scientific literacy within the broader South African educational context are discussed.
\end{abstract}

Keywords: Scientific inquiry, scientific literacy, inquiry-based learning.

\section{Introduction}

The teaching and learning of science through inquiry has been a key research focus area which provoked interest in scientific inquiry (Kruit, Oostdam, Van den Berg \& Schuitema, 2018). This is evidenced by a vast array of research studies which have been conducted focusing on teaching and learning through inquiry (e.g, Abell \& Lederman, 2007; Campbell, Abd-Hamid, \& Chapman, 2010; Flick $\&$ Lederman, 2004). While the development of learners' knowledge about scientific inquiry remains a key science education curriculum goal, a considerable number of secondary school learners continue to demonstrate naive understandings about scientific inquiry itself (Abd-El-Khalick \& Lederman, 2000a, 2000b). According to Flick and Lederman (2004), scientific inquiry primarily involves doing science and developing learners' understandings of the processes undertaken by scientists in developing scientific knowledge. Scientific inquiry requires learners to formulate their own questions, design and implement their own strategy, draw conclusions based on results from evidence and mathematical and analytical tools to derive a scientific claim (Olson \& Loucks-Horsley 2000; National Research Council, 2000). This research study is underpinned by inquiry in school science as the underlying theoretical framework. School science inquiry is largely viewed as similar to the inquiry done by professional scientists as learners also investigate the world, propose ideas and justify explanations based on collected evidence. However, school based inquiry is cognitively and epistemologically different from authentic scientific inquiry (research done by scientists) (Chinn \& Malhotra, 2002). School science learning activities are described by Vhurumuku, Holtman, Mikalsen and Kolstoe, (2004) as belonging to a continuum ranging from closed inquiry to open ended inquiry. Hofstein and Lunetta (2004) define scientific inquiry as various ways of studying the natural world, asking questions, proposing ideas, collecting evidence to justify assertions and explanations and communicating results. The significance of this research study stems from the fact that the Curriculum and Assessment Policy Statement for Physical Sciences puts greater emphasis on the development of learners' investigative skills required for inquiry-based learning (Department of Basic Education, 2011). This key strategic imperative hinges to a large degree on meaningful development of scientific inquiry skills. 


\section{Research design and methodology}

The study adopted a case study design and involved purposively selected Grade 11 Physical Sciences learners from two South African township schools. Data was collected by administering a validated Learner Perceptions of Classroom Inquiry (LPCI) instrument developed by Dudu and Vhurumuku (2012) with the participants. The validated instrument measures learners' perceptions of their experiences of scientific inquiry within the context of science classrooms.

\section{Findings}

Table 1 below provides distribution of learners' responses to the questionnaire items.

Table 1. Distribution of learners' responses.

\begin{tabular}{|c|c|c|c|c|c|}
\hline Item & $\begin{array}{c}\text { Almost } \\
\text { never }\end{array}$ & Seldom & $\begin{array}{c}\text { Some- } \\
\text { times }\end{array}$ & Often & $\begin{array}{l}\text { Almost } \\
\text { always }\end{array}$ \\
\hline \multicolumn{6}{|l|}{$\begin{array}{l}\text { A: Learners ask questions/framing research questions } \\
\text { in the science classroom }\end{array}$} \\
\hline $\begin{array}{l}\text { A1: I formulate questions which can be answered by } \\
\text { investigations }\end{array}$ & 25 & 15 & 4 & 3 & 3 \\
\hline $\begin{array}{l}\text { A2: My research questions are used to determine the } \\
\text { direction and focus of the lab }\end{array}$ & 20 & 26 & 2 & 1 & 1 \\
\hline A3: Framing my own research questions is important & 2 & 3 & 15 & 17 & 13 \\
\hline $\begin{array}{l}\text { A4: Time is devoted to refining my questions so that they } \\
\text { can be answered by investigations }\end{array}$ & 9 & 10 & 11 & 12 & 8 \\
\hline \multicolumn{6}{|l|}{ B: Designing investigations in the science classroom } \\
\hline $\begin{array}{l}\text { B1: I am given step-by-step instructions before they } \\
\text { conduct investigations }\end{array}$ & 6 & 8 & 13 & 11 & 12 \\
\hline B2: I design my own procedures for investigations & 15 & 20 & 8 & 4 & 3 \\
\hline $\begin{array}{l}\text { B3: We engage in the critical assessment of the procedures } \\
\text { that we employ when we conduct investigations }\end{array}$ & 13 & 23 & 9 & 3 & 2 \\
\hline $\begin{array}{l}\text { B4: We justify the appropriateness of the procedures that } \\
\text { are employed when we conduct investigations }\end{array}$ & 10 & 19 & 11 & 6 & 4 \\
\hline \multicolumn{6}{|l|}{ C: Conducting investigations in the science classroom } \\
\hline $\mathrm{C} 1$ : I conduct my own procedures of an investigation & 12 & 22 & 9 & 3 & 4 \\
\hline $\begin{array}{l}\text { C2: The investigation is conducted by the teacher in front } \\
\text { of the class }\end{array}$ & 2 & 2 & 6 & 25 & 15 \\
\hline $\begin{array}{l}\text { C3: I actively participate in investigations as they are } \\
\text { conducted }\end{array}$ & 3 & 18 & 19 & 7 & 3 \\
\hline C4: I have a role as investigations are conducted & 2 & 15 & 18 & 8 & 7 \\
\hline \multicolumn{6}{|l|}{ D: Collecting data in the science classroom } \\
\hline D1: I determine which data to collect & 9 & 18 & 6 & 8 & 9 \\
\hline $\begin{array}{l}\text { D2: I take detailed notes during each investigation along } \\
\text { with other data I collect }\end{array}$ & 8 & 12 & 10 & 11 & 9 \\
\hline D3: I understand why the data I am collecting is important & 4 & 10 & 17 & 14 & 5 \\
\hline $\begin{array}{l}\text { D4: I decide when data should be collected in an } \\
\text { investigation }\end{array}$ & 3 & 20 & 16 & 7 & 4 \\
\hline \multicolumn{6}{|l|}{ E: Drawing conclusions in the science classroom } \\
\hline E1: I develop my own conclusions for investigations & 4 & 8 & 18 & 12 & 8 \\
\hline $\begin{array}{l}\text { E2: I consider a variety of ways of interpreting evidence } \\
\text { when making conclusions }\end{array}$ & 7 & 10 & 20 & 8 & 5 \\
\hline E3: I connect conclusions to scientific knowledge & 8 & 10 & 11 & 12 & 9 \\
\hline E4: I justify my conclusions & 6 & 7 & 15 & 14 & 8 \\
\hline
\end{tabular}


As reflected in Table 1 above, the learners held mixed conceptions about the nature of scientific inquiry. In addition, the learners' conceptions were largely inconsistent with acceptable conceptions of scientific inquiry. The naïve and incoherent views expressed by the learners about the nature of scientific inquiry can partly be attributed to teachers' lack of professional competence and expertise in enacting inquiry-based teaching and learning.

\section{Discussion}

Meaningful enactment of inquiry-based learning as a contemporary pedagogic approach remains a fundamental challenge to teachers as key agents of educational change within the broader South African context. The views expressed by learners about the nature of scientific inquiry point to extensive exposure to instructional settings providing limited opportunities for learner autonomy when performing scientific investigations. Such instructional settings essentially serve to stifle meaningful development of inquiry skills required to perform plausible scientific investigations. The development of learners' knowledge about scientific inquiry remains a key science education curriculum goal. Yet, a considerable number of secondary school learners continue to demonstrate naive understandings about scientific inquiry (Abd-El-Khalick \& Lederman, 2000a, 2000b). There is a need for sustainable teacher professional development interventions which are specifically geared towards the enhancement of scientific investigation skills. The importance of nature of science and scientific inquiry as essential components of scientific literacy has been emphasized by several researchers (e.g. Lederman; Lederman \& Antink, 2013; Roberts, 2007). This key consideration underscores the need for the development of scientific investigation skills with a view to foster meaningful enhancement of human capital development in its broadest sense.

\section{Conclusion}

Meaningful enactment of inquiry-based teaching and learning remains a pervasive fundamental challenge for teachers within the broader South African context. The promotion of scientific inquiry as an essential tenet in science education hinges to a large degree on the inculcation of scientific investigation skills. Progressive realization of the inculcation of scientific investigation skills on a broader scale would serve to pave the way for meaningful development of scientific literacy as a science education key curriculum goal.

\section{References}

Abd-El-Khalick, F., \& Lederman, N. G. (2000). Improving science teachers' conceptions of nature of science: A critical review of literature. International Journal of Science Education, 22(7), 665-701.

Abd-El-Khalick, F., \& Lederman, N. G. (2000). The influence of history of science courses on students' views of nature of science. Journal of Research in Science Teaching, 37(10), 1057-1095.

Abell, S. K., \& Lederman, N. G. (Eds.). (2007). Handbook of Research on Science Education. Mahwah, NJ: Lawrence Erlbaum Associates.

Campbell, T., Abd-Hamid, N. H., \& Chapman, H. (2010). Development of Instruments to Assess Teacher and Student Perceptions of Inquiry Experiences in Science Classrooms. Journal of Management, 21(1), 13-30.

Chinn, C. A., \& Malhotra, B. A. (2002). Epistemologically authentic inquiry in schools: A theoretical framework for evaluating inquiry tasks. Science Education, 86, 175-218.

Department of Basic Education (DBE). (2011). Curriculum and Assessment Policy Statement. Pretoria Government Printer.

Dudu, W.T. \& Vhurumuku, E. (2012). Exploring South African Grade 11 learners' perceptions of classroom inquiry: validation of a research instrument. Science Education International, 23(2), 150-165.

Flick, L., \& Lederman, N. G. (2004). Scientific inquiry and nature of science: Implications for teaching, learning, and teacher education. The Netherlands: Kluwer Academic Publishers.

Hofstein, A., \& Lunetta, V. N. (2004). The laboratory in science education: Foundation for the $21^{\text {st }}$ century. Science Education, 88, 28-54. 
Kruit, P.M., Oostdam, R.J., Van der Berg, E.D. \& Schuitema, J.A. (2018). Assessing students' ability in performing scientific inquiry: Instruments for measuring science skills in primary education. Research in Science \& Technological Education, 36(4), 413-439.

Lederman, N. G., Lederman, J. S., \& Antink, A. (2013). Nature of science and scientific inquiry as contexts for the learning of science and achievement of scientific literacy. International Journal of Education in Mathematics, Science and Technology, 1(3), 138-147.

National Research Council. (2000). Inquiry and the National Science Education Standards. Washington, DC: National Academy Press.

Olson, S., Loucks-Horsley, S. (2000). Inquiry and the National Science Education Standards: A Guide for Teaching and Learning. Washington, DC: National Research Council.

Roberts, D. A. (2007). Scientific literacy/Science literacy. In S. K. Abell \& N. G. Lederman (Eds.), Handbook of Research on Science Education (pp. 729-780). London: Lawrence Erlbaum Associates.

Vhurumuku, E., Holtman, L., Mikalsen, O., \& Kolstoe, S. D. (2004). Attenuation equilibrium and laboratory ecological interaction: A study of A-level Chemistry students' laboratory work experiences and beliefs about the nature of science. Paper presented at the SAARMSTE conference in Windhoek, Namibia. 